\title{
One step ahead? The use of foresight by Czech and Slovak non-governmental organizations
}

\author{
Eva Šerá Komlossyová, Martin Schlossarek, Lucie Macková and Nikola Medová
}

\begin{abstract}
Non-governmental organizations (NGOs) are generally recognized as important actors in societies, fulfilling diverse sets of roles. Given the nature of their work and the complexity of the fast-changing contexts in which they operate, foresight techniques can potentially be useful in helping them prepare for future disruptions and maximize the positive influence of their work over future developments. The possibilities for and benefits of the application of foresight approaches and techniques are increasingly being discussed in various private and public organizations, especially with the aim to innovate and grow. However, little attention has been given to the question of how NGOs use foresight and whether their work benefits from it. The paper presents results of a survey conducted among Czech and Slovak NGOs active in development cooperation, humanitarian assistance, and environmental protection fields, filling the existing research gap by analyzing their application of foresight processes and the benefits foresight brings to them. The paper concludes that future-oriented processes in Czech and Slovak NGOs are of a rather informal and non-institutionalized nature, given the insufficient knowledge of foresight concepts and limited human capacities of NGOs. Nevertheless, they positively influence their creativity and growth.
\end{abstract}

Keywords: Strategic foresight, Non-governmental organizations, Development cooperation, Humanitarian assistance, Environmental protection, Czech Republic, Slovakia

\section{Introduction}

Strategic foresight is gradually becoming a concept broadly discussed in both private and public sectors for its assumed benefits in better preparing for and responding to future developments. Strategic foresight allows organizations and corporations to maintain a forward-looking view and to adapt or react to upcoming changes more effectively. Insight gained from strategic foresight can help them create a future-fit strategy, proactively attempt to influence the future, and therefore acquire a competitive advantage and stronger position in the market $[1,2]$.

What is largely missing in the current debate is whether and how non-governmental non-profit organizations can benefit from strategic foresight. Most

\footnotetext{
* Correspondence: eva.serakomlossyova@upol.cz

Department of Development and Environmental Studies, Palacký University Olomouc, 17. listopadu 12, 77146 Olomouc, Czech Republic
}

existing literature focuses on companies and corporations [3-6] and on the ways these actors apply strategic or corporate foresight and what benefits it creates. Little attention is given to the question of appropriateness and usefulness of foresight tools for non-governmental organizations (NGOs). Yet, their work is highly dependent on the enabling environment and they are to a considerable extent vulnerable to changes in funding, regulations, favor of supporters, and trust of partners and beneficiaries [7]. NGOs often aim for ambitious and multidimensional goals that are influenced by complex sets of trends and factors. It is safe to say that most of these organizations operate in fast-changing, complex, and volatile environments. As available research shows [3, 8, 9], these conditions generally define a higher need for strategic foresight.

\section{Springer Open}

(- The Author(s). 2020 Open Access This article is licensed under a Creative Commons Attribution 4.0 International License, which permits use, sharing, adaptation, distribution and reproduction in any medium or format, as long as you give appropriate credit to the original author(s) and the source, provide a link to the Creative Commons licence, and indicate if changes were made. The images or other third party material in this article are included in the article's Creative Commons licence, unless indicated otherwise in a credit line to the material. If material is not included in the article's Creative Commons licence and your intended use is not permitted by statutory regulation or exceeds the permitted use, you will need to obtain permission directly from the copyright holder. To view a copy of this licence, visit http://creativecommons.org/licenses/by/4.0/. 
This paper addresses the existing knowledge gap by analyzing the extent to which non-governmental organizations based in the Czech Republic and Slovakia apply foresight, and by identifying the types of foresight processes they engage in. We also intend to analyze the benefits of the application of strategic foresight for these NGOs. To narrow the research focus, we decided to survey NGOs primarily focusing on development cooperation, humanitarian assistance, and environmental protection. These sectors have a particularly high need for strategic foresight due to their complex and fastchanging character.

Our research takes into consideration the specific context of both the Czech Republic and Slovakia with regard to the general awareness of foresight as such. The term strategic or corporate foresight is rather unknown in both countries. Unlike in some other European countries where foresight has already taken an important role within private companies and public sector, in the former Czechoslovakia, the use of future-oriented practices is still limited. Strategic planning processes have been taking place in various fields of the public and private sectors; however, forward-looking tools are rarely being systematically integrated into these processes (for comprehensive analyses of the state of foresight in the Czech Republic and Slovakia, see [10, 11]).

\section{Theoretical background}

Rohrbeck [12] defines strategic foresight as a set of techniques, practices, and processes that organizations use for detecting new events and changes in their external environment, exploring their likely evolution and effects, and defining response options. The role of foresight is thus to prepare an organization for possible future challenges. The mechanism sets the learning processes that enable the flexibility and strategic agility of the organization. As a result, the organization's capability to respond to different changes and situations not only in its external environment increases [13].

Future studies, foresight, and especially strategic corporate foresight are, according to Daheim and Uertz [14], increasingly used for providing valuable inputs in the areas of strategic planning, research, technology development and innovation, but also for corporate communications and corporate identity/branding. Strategic foresight is regarded by a growing number of organizations as the tool of choice for preparing organizations for the future, be it in the form of a long-term strategic vision, ideas for innovations, or a scenario used for communication purposes. Strategic foresight is considered as a proactive step for coping with uncertainties in the organizational environment and beyond. Organizations also use foresight to connect or identify themselves with the future in general, creating their brand of a future- proof and futurizing organization, a force shaping the future, not merely reacting to trends.

To enhance foresight practices of various stakeholders, several authors attempted to create a comprehensive model identifying the best practices in strategic foresight that would serve as a tool for benchmarking and assessment of foresight competences of individuals and organizations [12]. At the individual level, Hines et al. [15] proposed the Foresight Competency Model to evaluate skills and abilities of foresight practitioners. Day and Schoemaker [8] introduced the peripheral vision capability concept which assesses the scanning capacities of organizations. Two other, more complex models assessing maturity of diverse foresight practices in organizations, are Rohrbeck's [12] Maturity Model of Corporate Foresight and Grim's [16] Foresight Maturity Model. In our study, we adopted a simplified version of Terry Grim's [16] model to assess foresight maturity of NGOs, as it is applicable to organizations and covers all steps of the widely-accepted Thinking about the Future framework for strategic foresight, developed by Hines and Bishop $[17,18]$ : leadership, framing, scanning, forecasting, visioning, and planning. The model and the way it was simplified for the application in our research are further described in the Methodology section.

Foresight is assumed to provide a number of benefits to organizations that apply future-oriented practices. While some authors claim that there is still a gap between future studies and organizational management [19], companies using foresight appear to be more innovative than the ones which do not $[20,21]$. Therefore, our first hypothesis is that foresight-oriented NGOs are more creative compared to NGOs that do not apply foresight. Similarly to foresight, innovation is a horizontal cross-cutting matter which affects developments in various domains [22]. Innovative companies can monitor the external weak signals and trends, which can be incorporated into their strategic direction [20]. Moreover, the ability to develop strategic foresight is vital for companies in the rapidly changing environment in terms of a continuous process of innovation [21]. Rohrbeck and Gemünden [6] found that one of the ways foresight can drive the innovation capacity of a company is through its initiator role, which increases the number of innovative concepts and ideas. By the same token, Rohrbeck and Schwarz [4] found that value in multinational companies is generated through an enhanced capacity to interpret and respond to change. Moreover, their case studies have also shown that strategic foresight can support new product development [4]. The use of foresight as a tool of innovation management in companies can be beneficial for individual stakeholders. An empirical study among 152 large European companies shows that $57.5 \%$ of the respondents perceive corporate foresight as 
an improvement of the innovation process [23]. Therefore, according to the literature, the use of foresight in companies can spark innovation as well as create value, i.e., through product development.

Next, we focus on the growth in organizations with the hypothesis that foresight-oriented NGOs grow faster compared to NGOs that do not apply foresight. In doing this, we understand growth as a holistic value. Research by Rohrbeck et al. [24] shows that companies which "invest significantly more resources in gathering data from restricted sources, utilize more qualitative methods, and more often select [foresight] methods deliberately" (32) are top-performing in terms of their growth. Moreover, they also found that in top performing companies, foresight activities are more bottom-up triggered which further contributes to the alertness in the companies. Similarly, Rohrbeck and Schwarz [4] studied the contribution of formalized strategic foresight activities to value creation. The value in the company is not only monetary but also pertains to the capacity to interpret changes, organizational learning, and the capacity to influence other actors. The 77 companies in the study were divided into three categories, based on sales volume. The data show that $42 \%$ of top performers and $23 \%$ and $25 \%$ of medium and low performers respectively say that their strategic foresight activities contribute to creating value in the company. Moreover, the top performers are better at capturing the overall portfolio of value creation.

Finally, we expect that the foresight orientation affects stability of NGOs. The issue of effect of foresight orientation is riddled with contradictions. The use of foresight methods can have a positive impact on stability because the foresight-oriented organizations are better prepared for the future. While stability is required for the efficiency of the organizations, it can also mean that more stable organizations are more rigid in their processes [25]. This also relates to the NGOs which were targeted in this survey as some of them might struggle with changing donor landscapes or high employee fluctuation rates. Most organizations are not prepared to deal with problems in the turbulent environment [26]. Therefore, the use of foresight can present a competitive advantage. This is especially important for SMEs (small and medium-sized enterprises). As Dudin et al. [27] put it, "the strategic sustainability of small and medium-size business structures is their ability to operate and develop during a long time with relatively stable dynamics, when the accumulated economic potential is systematically transformed to the incentives of the balanced socioeconomic growth" (1086). The NGOs targeted in this survey can be, for the most part, considered small and medium-sized. Therefore, some stability is needed for the organizations, but stability should not affect the capacity to innovate.

\section{Methodology}

To assess the extent to which Czech and Slovak NGOs apply future-oriented strategic processes and to identify the benefits these processes bring, we collected mostly quantitative data using an online-based questionnaire. The questionnaire was divided into three parts.

The first part aimed at identifying which of the processes understood as essential phases of strategic foresight are being applied by NGOs. When constructing the questionnaire, we were primarily inspired by the Bishop and Hines's steps of strategic foresight $[17,18]$ and Terry Grim's Foresight Maturity Model (FMM) [16]. In the FMM, Grim works with five maturity levels, from Ad hoc as the basic maturity level to the highest World class level, and identifies maturity indicators at each of the maturity levels for practices in six foresight disciplines. We have, nevertheless, considered the premise that Czech and Slovak NGOs are mostly unaware of foresight concepts (which has been proved by our survey- $77 \%$ of respondents indicated they have never encountered the terms foresight or future studies). Therefore, we decided to simplify Grim's otherwise complex model to a considerable degree. Instead of measuring the degree of maturity of NGOs in foresight disciplines, we only inquired about the existence of practices related to leadership, scanning, forecasting, planning, and visioning ${ }^{1}$ disciplines in the participating NGOs (for specific questions asked in the questionnaire please see variables for the first dimension of FOR in Table 1).

As Grim's Foresight Maturity Model looks mostly at the formal/procedural aspects of foresight practices, we supplemented the FMM with an additional assessment of the thematic focus of future-oriented processes. In the second part of the questionnaire we followed the structure of the Horizon scanning technique, assessing the extent to which NGOs engage in searching for weak signals in their inner, immediate, and global environment. For the global level, we inquired about the STEEP areas: social, technological, economic, environmental, and political [28, 29] (for specific questions asked in the questionnaire please see variables for the second dimension of FOR in Table 1).

The third part of the survey targeted those characteristics of NGOs that can potentially be impacted by foresight, as identified in the theoretical background. NGOs were asked to provide their self-assessment of how innovative, inspirational, and important they are compared to other Czech/Slovak NGOs in their sector. They were also questioned about their financial and personal growth in the past 5 years and about the experiences with crises related to human and financial capacities and

\footnotetext{
${ }^{1}$ We dropped the Framing discipline, as it refers to a specific foresight activity or project. We were interested in the overall processes as established and practiced by NGOs; hence, we assessed this discipline as being irrelevant for our inquiry.
} 
Table 1 Structure of the Foresight Orientation Ratio (FOR)

\begin{tabular}{lc}
\hline Variables & Weights \\
\hline 1st dimension: application of foresight-oriented processes \\
We have a person responsible for foresight-oriented work \\
I agree & -3.447 \\
Other answers & 0.242 \\
We monitor signals of possible future changes and trends \\
I agree & -1.613 \\
Other answers & 0.675 \\
We formulate future scenarios in relevant fields \\
I agree & -2.622 \\
Other answers & 0.514 \\
We evaluate possible future's impact on our NGO \\
I agree & -2.773 \\
Other answers & 0.480 \\
We consider possible future trends when creating strategic plan \\
I agree & -1.009 \\
Other answers & 0.422 \\
We intend to intentionally influence the future in relevant fields \\
I agree & -1.524 \\
Other answers & 0.638
\end{tabular}

\section{2nd dimension: coverage of foresight-related topics}

We monitor and evaluate future trends in internal environment of our NGO

$$
\begin{array}{ll}
\text { I agree } & -0.769 \\
\text { Other answers } & 0.348
\end{array}
$$

We monitor and evaluate future trends in external sources of financing

$$
\begin{array}{ll}
\text { I agree } & -0.621 \\
\text { Other answers } & 0.642
\end{array}
$$

We monitor and evaluate future trends in other relevant NGOs' activities

$$
\begin{array}{ll}
\text { I agree } & -1.365 \\
\text { Other answers } & 0.717
\end{array}
$$

We monitor and evaluate future trends in relevant regions

$$
\begin{array}{ll}
\text { I agree } & -1.859 \\
\text { Other answers } & 0.661
\end{array}
$$

We monitor and evaluate future trends in relevant sectors

$$
\begin{array}{ll}
\text { I agree } & -1.241 \\
\text { Other answers } & 0.922
\end{array}
$$

We monitor and evaluate future trends in global climate and environment

$\begin{array}{ll}\text { I agree } & -1.666 \\ \text { Other answers } & 0.753\end{array}$

We monitor and evaluate future trends in global economics

$$
\begin{array}{ll}
\text { I agree } & -2.652 \\
\text { Other answers } & 0.400
\end{array}
$$

We monitor and evaluate future global societal, cultural, and demographic changes
Table 1 Structure of the Foresight Orientation Ratio (FOR) (Continued)

\begin{tabular}{ll}
\hline Variables & Weights \\
\hline I agree & -2.286 \\
Other answers & 0.560 \\
We monitor and evaluate future trends in global politics \\
I agree & -2.521 \\
Other answers & 0.555
\end{tabular}

We monitor and evaluate future trends in local Czech/Slovak politics

$\begin{array}{ll}\text { I agree } & -1.879 \\ \text { Other answers } & 0.560\end{array}$

We monitor and evaluate future technological changes and innovations

$$
\begin{array}{ll}
\text { I agree } & -2.492 \\
\text { Other answers } & 0.376
\end{array}
$$

${ }^{2}$ Other answers are as follows: somewhat agree, somewhat disagree, disagree, and do not know

with failures to fulfill the planned goals. We included an open question at the end of the questionnaire allowing respondents to express their views on the importance and potential usefulness of foresight for their work.

We decided to run the full version of the questionnaire for all NGOs, including those indicating no previous knowledge of the concept at the beginning of the survey, to test the possibility that organizations do make use of processes generally encompassed within foresight without being formally aware of the concept and its methods.

In our research, we targeted NGOs with the potentially highest need for strategic foresight, which are primarily organizations functioning in fast-changing, complex environments, and those with multi-dimensional goals that depend on numerous factors and trends. Hence, we focused on NGOs working in development cooperation, humanitarian assistance, and environmental protection, including NGOs providing global development and environmental education and awareness-raising programs. The survey was sent to representatives, mostly executive managers, of 120 Czech and 104 Slovak NGOs. To create the database of active NGOs, we first searched the websites of platforms or umbrella organizations that gather NGOs with similar thematic focus (e.g., FoRS [30], Zelený kruh [31], and Pavučina [32] in the Czech Republic, NGDO Platform [33] in Slovakia). To complete the list of Czech organizations, we then made use of the Givt website [34] that allows customers of e-shops to contribute a small portion of their online purchase towards the work of a selected Czech NGO. We assumed that most active NGOs are interested in such fundraising opportunities and are registered with Givt ${ }^{2}$. In Slovakia, we browsed the NGO

\footnotetext{
${ }^{2}$ The Givt website currently gathers more than 4500 Czech NGOs working in huge variety of sectors and fields (personal communication on July 2, 2019).
} 


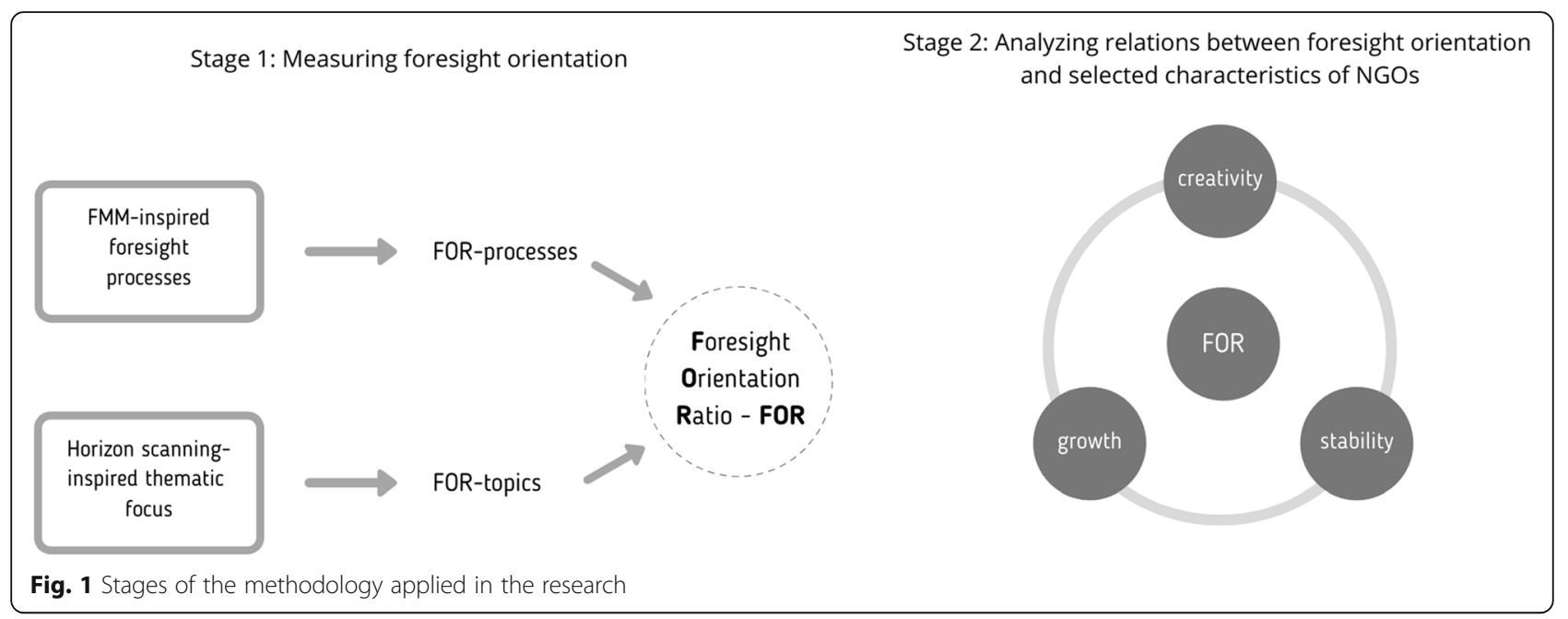

catalogue on the zoznam.sk website [35]. We used these websites instead of government databases of non-profit nongovernmental organizations to avoid contacting a large number of non-active NGOs. The government databases contain all NGOs that have ever been registered at a local court, as NGOs do not have the obligation to cancel their registration once they cease their operations. In total, we collected 61 responses (response rate of 27\%).

Out of the 61 NGOs participating in the survey, 14 organizations work in development cooperation, $10 \mathrm{in} \mathrm{hu-}$ manitarian assistance, and 31 in environmental protection. In total, $32 \mathrm{NGOs}$ indicated they are active in environmental/ecological education and 15 in global development education ${ }^{3}$. Most of the organizations, 49 in total, have been active for at least 10 years. Similarly, a majority of respondents, 41 NGOs, have fewer than 10 full-time employees, and only three have 50 employees or more.

\section{Statistical analysis}

We operationalize the level of foresight orientation of NGOs by the Foresight Orientation Ratio (FOR). FOR consists of two dimensions: (i) the application of foresight oriented processes (FOR-processes) and (ii) the coverage of foresight-related topics (FOR-topics), as depicted in Fig. 1.

There are two frequently challenged issues in the construction of composite indices. The first one is weighting: OECD [36] lists seven methods for setting weights and these can be classified in two categories. Weights can either be determined by expert/participatory assessment or by statistical models. Various statistical weighting methods based on characteristics of the data are usually used, such as multiple correspondence analysis

\footnotetext{
${ }^{3}$ Respondents were asked to indicate all fields they work in, allowing them to choose more than one field.
}

(used e.g., by Bernardo et al. [37] and Boccanfuso et al. [38]), principal component analysis (used e.g., by Olawale and Garwe [39]) or fuzzy analysis (used e.g., by Oyekale and Oyekale [40]). In our research, we used the multiple correspondence analysis (MCA) for each dimension as it is one of the most popular factorial analysis techniques and it is also one which is easy to adapt to the structure of the data we collected.

The second challenge is to decide which dimensions and indicators should be included in the index. More is not better: on the ground of parsimony, omitting variables should be always considered. As choices made during the abovementioned processes are arbitrary, it is sensible to test the sensitivity of results of an index on decisions taken ${ }^{4}$.

Table 1 presents the final structure of the index together with (non-rescaled) weights of each variable. In total, 17 binary variables were used for the calculation of FOR: six of them were included in the dimension focused on processes, 11 were included in the dimension focused on covered topics.

After the calculation of FOR-processes, FOR-topics, and FOR, we undertook the sensitivity analysis. We did it in two phases: in the first phase, we adjusted the weights of variables used in both dimensions. Instead of weights determined by MCA, we used equal weights: 1 for pro-foresight response to each question (i.e., "I agree"), 0 for other responses. We found that there is a very strong positive correlation $(r=0.98)$ between the original and adjusted FOR. In the second stage of sensitivity analysis, we focused on indicators used in the index. We have decided to continue using equal weights

${ }^{4}$ Other challenging issues when constructing composite indices include the standardization and normalization of data. However, as FOR consists of categorical variables only, the issue is not as important as in other cases. 
in both dimensions and to calculate two other adjusted versions of FOR: in the first version, we dropped the first three variables used in FOR-processes and the first five variables used in FOR-topics (as presented in Table 1); in the second version, we dropped the last three variables used in FOR-processes and the last six variables used in FOR-topics. Correlation between these adjusted versions and original version remains very high: 0.93 in case of the first version and 0.91 in case of the second version. Therefore, we concluded that the outcomes of the original FOR are robust and relatively insensitive to normative decisions we have made during the process of its construction.

In the final step, we rescaled the results of the original FOR linearly in a manner which assigns 0 points to those NGOs with the lowest orientation on foresight in the respective dimension and 100 to NGOs with the highest orientation on foresight in respective dimension. FOR was calculated as an arithmetic average score of both dimensions. The summary statistics for the final version of FOR and its two dimensions are displayed in Table 2.

We can see that the median for FOR-processes is 0 , since 33 out of 61 respondents scored 0 in this dimension of the indicator. This is in line with our argument that Czech and Slovak NGOs are rather unaware of formal foresight processes. At the same time, only 18 out of 61 NGOs scored 0 in FOR-topics, indicating that intuitively most NGOs do follow future trends in some areas, even without being familiar with foresight as a concept.

The statistical analysis of data was based on the following three assumptions inferred from the theoretical part of the paper presenting the literature review of the potential benefits of the application of strategic foresight:

1. foresight-oriented NGOs should be more creative compared to NGOs that do not apply foresight

2. foresight-oriented NGOs should grow faster compared to NGOs that do not apply foresight

Table 2 Summary statistics for FOR and its dimensions

\begin{tabular}{llll}
\hline & FOR & FOR-processes & FOR-topics \\
\hline No. of observations & 61 & 61 & 61 \\
Minimum value & 0 & 0 & 0 \\
Maximum value & 97.84 & 100 & 100 \\
Mean & 21.87 & 18.62 & 25.13 \\
Median & 11.80 & 0 & 14.64 \\
Standard deviation & 25.09 & 29.20 & 30.56 \\
Skewness & 1.20 & 1.60 & 1.25 \\
Kurtosis & 3.59 & 4.31 & 3.36 \\
\hline
\end{tabular}

3. foresight-oriented NGOs should have different level of stability compared to NGOs that do not apply foresight

For detailed definitions of the terms "creativity," "growth," and "stability" in the context of the abovelisted assumptions, please see Table 3.

To verify the assumptions, the null hypotheses presented in Table 3 were tested on 5\% significance level against the respective alternative hypothesis. The Fisher's exact test was used to test them. As we did multiple testing (three tests per each assumption), the Šidák method of correction [41] was used to adjust critical level of $p$ values. The analysis was carried out using the Stata 12 program.

For the purpose of the hypotheses testing, we defined foresight-oriented NGOs as those with scores of FOR higher than the median (see Table 2). The remaining NGOs were deemed as "NGOs that do not apply foresight." Analogical procedure was used in case of hypotheses based on FOR-processes and FOR-topics. We are fully aware that, in general, the future orientation of NGOs in the Czech Republic and Slovakia is rather low (as mentioned above, 77\% of respondents are not familiar with the term foresight). It would be more appropriate to call these NGOs as "NGOs which-compared to other NGOs in the Czech Republic and Slovakia-engage more in foresight-related processes." We label such NGOs as "foresight-oriented NGOs" for the sake of simplicity of the language. They are foresight-oriented only relatively to other researched NGOs, but not in absolute terms.

Table 3 summarizes the results of the Fisher's exact test for all hypotheses tested during the data analysis.

\section{Findings}

In our analysis, we have tested three triplets of hypotheses to identify what effect strategic foresight has on NGOs that claim to be future-oriented in their internal processes. We compared foresight-oriented NGOs with NGOs that do not apply foresight, focusing on three dimensions. The first dimension, creativity, combined the self-assessed innovativeness of organizations with the extent to which they and their work serve as an inspiration to other NGOs in the relevant sector. Second, organizational growth was operationalized by four variables: (i) the relative importance of an NGO in its sector, (ii) the image of an NGO (both variables based on the self-assessment of NGOs), (iii) the financial turnover, and (iv) the number of employees in an organization. We asked whether an organization has experienced growth in these four areas in the past 5 years. Finally, stability was assessed based on the reported occurrence of crises in terms of human resources, financial 
Table 3 Results of Fisher's exact tests

\begin{tabular}{|c|c|c|}
\hline Hypotheses & Results & Notes \\
\hline $\begin{array}{l}\mathrm{H1} \text { : proportion of creative NGOs is higher among foresight- } \\
\text { oriented NGOs }\left(p_{1}\right) \text { compared to NGOs that do not apply } \\
\text { foresight }\left(p_{2}\right) . p_{1}>p_{2}\end{array}$ & $\begin{array}{l}p_{1}=58.1 \%(n=31) \\
p_{2}=30.0 \%(n=30) \\
\boldsymbol{p}=\mathbf{0 . 0 2 5 ^ { * }}\end{array}$ & \multirow{3}{*}{$\begin{array}{l}\text { Binary variable based on self-assessment of the organizational } \\
\text { level of innovativeness and of how inspirational an NGO is to } \\
\text { other NGOs in its field was used to operationalize the level of } \\
\text { creativity. NGO was deemed as creative only when a respondent } \\
\text { agreed that NGO is either innovative or inspirational to other } \\
\text { NGOs and at the same time did not deny that NGO is either in- } \\
\text { novative or inspirational to other NGOs. }\end{array}$} \\
\hline $\begin{array}{l}\text { H1a: same as above but based on FOR-processes instead of } \\
\text { FOR }\end{array}$ & $\begin{array}{l}p_{1}=64.3 \%(n=28) \\
p_{2}=27.3 \%(n=33) \\
\boldsymbol{p}=\mathbf{0 . 0 0 4 ^ { * }}\end{array}$ & \\
\hline H1 b: same as above but based on FOR-topics instead of FOR & $\begin{array}{l}p_{1}=54.8 \%(n=31) \\
p_{2}=33.3 \%(n=30) \\
p=0.076\end{array}$ & \\
\hline $\begin{array}{l}\text { H2: proportion of growing NGOs is higher among foresight- } \\
\text { oriented NGOs }\left(p_{1}\right) \text { compared to NGOs that do not apply } \\
\text { foresight }\left(p_{2}\right) . p_{1}>p_{2}\end{array}$ & $\begin{array}{l}p_{1}=41.9 \%(n=31) \\
p_{2}=20.0 \%(n=30) \\
p=0.057\end{array}$ & \multirow{3}{*}{$\begin{array}{l}\text { Binary variable was used to measure the growth. It was based on } \\
\text { answers to the question of whether the NGO in the past } 5 \text { years: } \\
\text { (i) has become more important in the sector of NGO's interest } \\
\text { (self-assessment), (ii) has improved its image (self-assessment), (iii) } \\
\text { has increased the financial turnover, and (iv) has increased the } \\
\text { number of employees. NGO was deemed as growing only when } \\
\text { the answer was positive at least in one case and at the same } \\
\text { time was not negative in any of the cases. }\end{array}$} \\
\hline $\begin{array}{l}\text { H2a: same as above but based on FOR-processes instead of } \\
\text { FOR }\end{array}$ & $\begin{array}{l}p_{1}=46.4 \%(n=28) \\
p_{2}=18.2 \%(n=33) \\
\boldsymbol{p}=\mathbf{0 . 0 1 8 ^ { * }}\end{array}$ & \\
\hline H2b: same as above but based on FOR-topics instead of FOR & $\begin{array}{l}p_{1}=41.9 \%(n=31) \\
p_{2}=20.0 \%(n=30) \\
p=0.057\end{array}$ & \\
\hline $\begin{array}{l}\text { H3: proportion of stable NGOs among foresight-oriented } \\
\text { NGOs }\left(p_{1}\right) \text { is different than among NGOs that do not apply } \\
\text { foresight }\left(p_{2}\right) \cdot p_{1} \neq p_{2}\end{array}$ & $\begin{array}{l}p_{1}=16.1 \%(n=31) \\
p_{2}=30.0 \%(n=30) \\
p=0.235\end{array}$ & \multirow{3}{*}{$\begin{array}{l}\text { Binary variable was used to measure the level of stability. It was } \\
\text { based on answers to the question of whether the NGO, in the } \\
\text { past } 5 \text { years, faced a crisis in terms of the following: (i) human } \\
\text { resources ("the organization suffered from the lack of competent } \\
\text { employees"), (ii) financial resources ("the source of funding for } \\
\text { the following } 6 \text { months was very unsure"), and (iii) failure to } \\
\text { meet planned objectives (..."due to unexpected events"). When } \\
\text { the answer in all three cases was negative, NGO was deemed to } \\
\text { be stable. }\end{array}$} \\
\hline $\begin{array}{l}\text { H3a: same as above but based on FOR-processes instead of } \\
\text { FOR }\end{array}$ & $\begin{array}{l}p_{1}=21.4 \%(n=28) \\
p_{2}=24.2 \%(n=33) \\
p=1.000\end{array}$ & \\
\hline H3b: same as above but based on FOR-topics instead of FOR & $\begin{array}{l}p_{1}=19.4 \%(n=31) \\
p_{2}=26.7 \%(n=30) \\
p=0.554\end{array}$ & \\
\hline
\end{tabular}

Statistically significant results in bold

resources, and achievement of planned objectives. Each hypothesis was tested for the total FOR, FOR-processes, and FOR-topics.

Out of the hypotheses tested, three were proved at a statistically significant level. First, results show that foresightoriented NGOs are more creative than NGOs that do not apply foresight. This hypothesis was proved for both the overall FOR as well as for FOR-processes. When the calculation was based on FOR-topics, the results were not significant, although the difference in the proportions of creative NGOs between both groups of NGOs $(54.8 \%$ foresight-oriented NGOs are creative compared to $33.3 \%$ among NGOs not applying foresight) can be interpreted as a very soft evidence supporting our expectations. Hence, we concluded that foresight has a positive effect on the creativity of NGOs, with application of foresight processes playing a particularly important role.

The analysis also hints that foresight-oriented NGOs experience growth more often than NGOs not applying foresight. The difference between foresight-oriented and other NGOs is statistically significant only when foresight orientation is defined by FOR-processes. The hypotheses for overall FOR and FOR-topics were not significant, though the difference in proportions goes in the expected direction $(41.9 \%$ versus $20.0 \%$ in both cases). As when testing the effects on creativity, growth also seems to be positively affected by the application of foresight processes to a higher extent than by focusing on various foresight topics. It seems that the topics an NGO follows in its future-oriented work are less important than the existence of foresight processes themselves.

The results for hypotheses inquiring about the effects of the foresight orientation on the stability of an organization are much more ambiguous. The test results were insignificant for all three indicators of foresight orientation. No particular trend can be identified in our data. This finding is consistent with the existing literature that similarly provides inconclusive answers on how foresight influences the stability of organizations. It does not mean that the effect does not exist: our power to prove any hypothesis is limited by the limited number of respondents and further research is needed in this area.

Apart from the results of hypotheses testing, there are other important issues the research sheds some light on when it comes to the maturity of foresight processes in the researched NGOs. Our data show that to a large extent Czech and Slovak NGOs cannot be considered intentionally foresight-oriented. A large majority, $77 \%$ of respondents indicated that they are not familiar with the foresight or future studies concept. Only two respondents out of 61 declared that they are familiar with foresight and actively apply it in their work. Still, questions 
directed towards the existence of future-oriented processes in organizations provided mostly positive results. If we look at the proportion of respondents strongly or somewhat agreeing with statements concerning the existence of foresight processes, $85 \%$ of organizations indicated that they scan their environment for signals of possible upcoming changes, $59 \%$ make scenarios of possible future developments, $64 \%$ assess potential impact of future developments on their organization, $66 \%$ prepare a future-oriented strategic plan, and $80 \%$ of organizations declared they are trying to influence the future in areas relevant to their scope of work to support the positive development and avoid negative future changes. At the same time, however, $70.5 \%$ of organizations do not have an employee assigned with foresight responsibilities. Hence, we concluded that foresight processes that NGOs claim to be performing are of rather intuitive, ad hoc nature, and are not systematized and/or institutionalized in the majority of the researched NGOs.

As evident from answers to the open question inquiring about the perceived importance and role of foresight for the work of NGOs, respondents see the importance of looking forward when managing an organization, with $75 \%$ of responses expressing positive or somewhat positive view on foresight and its importance. However, formal knowledge of foresight techniques and methods remains low and the processes are performed mostly at basic, intuitive level. Insufficient capacities also play a role here, as one respondent concluded, "I see it as a usual managerial approach in regular organizations. In our situation, we simply do not have the capacity, that's why we improvise." Another respondent stated, "[...] It is unthinkable for the only full-time employee of an NGO to perform all the tasks that are being done by a whole unit in companies [...]."

\section{Conclusion}

The research among Czech and Slovak NGOs working in development cooperation, humanitarian assistance and environmental protection fields analyzed the extent to which these NGOs apply foresight processes and what benefits the foresight orientation brings to them. Based on the presented data we formulated the following conclusions.

Consistent with the generally low awareness of the foresight concept in both the Czech Republic and Slovakia, NGOs in these two countries are also to a large degree unfamiliar with the strategic foresight and its formalized methods. Nevertheless, the NGOs targeted with the research potentially have a high need for foresight, given the character of their sectors and context in which they operate. Intuitively they see the importance of looking forward when managing an organization, considering it a good management practice. Yet, the vast majority of organizations do not have an employee responsible for conducting the foresight-oriented work for the organization.

Even though the future-oriented processes are assumed to be of rather informal and non-institutionalized nature, given the insufficient knowledge of foresight and limited human capacities of NGOs, they nevertheless positively influence the creativity and growth of NGOs. NGOs that are foresight-oriented in their strategic processes are more innovative, inspirational to others, and are growing more rapidly than NGOs that do not apply foresight in their work. Compared to foresight-oriented processes, the degree to which NGOs focus on various topics in their forward-looking practice seems to have a lower effect on creativity and growth of NGOs. The influence of foresight orientation on the stability of an organization remains unclear, with results of our hypothesis testing indicating no clear trend.

It is important to acknowledge that the main conclusions of this paper are based on the self-assessment of NGOs. For example, assessment of the level of innovativeness of NGOs is based on answers to the question of whether the NGOs think they are among "the most innovative organizations in their field and in the country." We are aware of the fact that answers based on such self-assessment might be affected by unintended bias. Further research based on hard, objective, data would be informative, though it is clear that NGOs tend to be rather hesitant to share their, often sensitive, financial, personal, and managerial data with external researchers. We see our analysis as a first attempt to assess the foresight practice of the specific type of actor that remains under-represented in the existing literature. Non-profit non-governmental organizations undoubtedly work under specific circumstances, different from for-profit organizations, and identification of foresight approaches suitable to their specific situation and needs is therefore necessary. We hope this research inspires further discussion among academics and practitioners on the factors that impede NGOs to fully apply foresight techniques and leverage the full benefits strategic foresight has proved to yield.

\section{Acknowledgements \\ Not applicable}

\section{Authors' contributions}

All authors discussed the research design and methodology. EŠK collected the data, drafted the Introduction, Findings and Conclusion sections, and completed the final draft. MS conducted the statistical analysis of the collected data and interpreted the data. LM and NM made contributions to the theoretical part of the paper. All author(s) read and approved the final manuscript.

\section{Funding}

The presented research was funded by the Internal Grant Agency of Palacký University Olomouc, within the project number IGA_PrF_2018_018. 


\section{Availability of data and materials}

The dataset used and analyzed during the presented study is available from the corresponding author on reasonable request.

\section{Ethics approval and consent to participate}

Not applicable

\section{Consent for publication}

Not applicable

Received: 7 August 2019 Accepted: 25 March 2020

Published online: 23 April 2020

\section{References}

1. Slaughter R (1997) Developing and applying strategic foresight. ABN Rep 5

2. Battistella C, Huizingh $E$, Rohrbeck R (2015) Corporate foresight: an emerging field with a rich tradition. Technol Forecast Soc Change 101:1-9 https://doi.org/10.1016/j.techfore.2015.11.002

3. Rohrbeck R, Kum ME (2018) Corporate foresight and its impact on firm performance: a longitudinal analysis. Technol Forecast Soc Change 129:105116 https://doi.org/10.1016/j.techfore.2017.12.013

4. Rohrbeck R, Schwarz JO (2013) The value contribution of strategic foresight: insights from an empirical study of large European companies. Technol Forecast Soc Change 80:1593-1606 https://doi.org/10.1016/j.techfore.2013. 01.004

5. Thom N (2010) Measuring the value contribution of corporate foresight. 3rd ISPIM Innov Symp, Quebec City

6. Rohrbeck R, Gemünden HG (2011) Corporate foresight: its three roles in enhancing the innovation capacity of a firm. Technol Forecast Soc Change 78:231-243 https://doi.org/10.1016/j.techfore.2010.06.019

7. Fioramonti L, Kononykhina $\mathrm{O}$ (2015) Measuring the enabling environment of civil society: a global capability index. Voluntas 26:466-487. https://doi. org/10.1007/s11266-014-9444-3

8. Day GS, Schoemaker PJH (2005) Scanning the periphery. Harv Bus Rev 83: 135-148

9. Juech C, Michelson ES (2012) Innovation in horizon scanning for the social sector: an introduction to the Searchlight function. Foresight 14:439-449 https://doi.org/10.1108/14636681211284908

10. Valenta $O$ (2016) Status quo of the corporate foresight in the Czech Republic. In: Sacio-Szymańska A (ed) Corporate foresight potential in Visegrad (V4) countries. Institute for Sustainable Technologies - National Research Institute in Radom, Radom, pp 23-36

11. Markovič P, Gubová K, Boorová B (2016) Status quo of foresight in Slovakia. In: Sacio-Szymańska A (ed) Corporate foresight potential in Visegrad (V4) countries. Institute for Sustainable Technologies - National Research Institute in Radom, Radom, pp 64-75

12. Rohrbeck R (2010) Corporate foresight: towards a maturity model for the future orientation of a firm. Springer-Verlag, Berlin

13. Vecchiato $R$ (2015) Creating value through foresight: first mover advantages and strategic agility. Technol Forecast Soc Chang 101:25-36. https://doi.org/ 10.1016/j.techfore.2014.08.016

14. Daheim C, Uerz G (2008) Corporate foresight in Europe: from trend based logics to open foresight. Technol Anal Strateg Manag 20:321-336 https:// doi.org/10.1080/09537320802000047

15. Hines A, Gary J, Daheim C, van der Laan L (2017) Building foresight capacity: toward a foresight competency model. World Futur Rev 9:123-141 https:// doi.org/10.1177/1946756717715637

16. Grim T (2009) Foresight Maturity Model (FMM): Achieving best practices in the foresight field. J Futur Stud 13:69-80

17. Hines A, Bishop PJ (2006) Thinking about the future: guidelines for strategic foresight. Social Technologies, Washington, D.C.

18. Hines A, Bishop PJ (2015) Thinking about the future: guidelines for strategic foresight, 2nd edn. Hinesight, Houston

19. van der Steen M, van Twist M, van der Vlist M, Demkes $R$ (2011) Integrating futures studies with organizational development: design options for the scenario project "RWS2020.". Futures 43:337-347 https://doi.org/10.1016/j. futures.2010.02.002

20. Battistella C, De Toni AF (2011) A methodology of technological foresight: a proposal and field study. Technol Forecast Soc Change 78:1029-1048 https://doi.org/10.1016/j.techfore.2011.01.006
21. Costanzo LA (2004) Strategic foresight in a high-speed environment. Futures 36:219-235 https://doi.org/10.1016/S0016-3287(03)00145-9

22. Havas A, Schartinger D, Weber M (2010) The impact of foresight on innovation policy-making: recent experiences and future perspectives. Res Eval 19:91-104 https://doi.org/10.3152/095820210×510133

23. Daheim C, Uerz G (2006) Corporate foresight in Europe: ready for the next step? In: Second International Seville Seminar on Future-Oriented Technology Analysis: Impact of FTA Approaches on Policy and DecisionMaking, pp 1-16

24. Rohrbeck R, Mahdjour S, Knab S, Frese T (2009) Benchmarking report: strategic foresight in multinational companies

25. Doz YL, Kosonen M (2010) Embedding strategic agility: a leadership agenda for accelerating business model renewal. Long Range Plann 43:370-382 https://doi.org/10.1016/j.lrp.2009.07.006

26. Ringland G (2010) The role of scenarios in strategic foresight. Technol Forecast Soc Change 77:1493-1498 https://doi.org/10.1016/j.techfore.2010. 06.010

27. Dudin MN, Ljasnikov NV, Pankov SV, Sepiashvili EN (2013) Innovation foresight as a tool of competitive development of business entities. World Appl Sci J 26:1086-1089 https://doi.org/10.5829/idosi.wasj.2013.26.08.13550

28. Bishop P (2009) Horizon scanning why is it so hard?

29. Hammoud MS, Nash DP (2014) What corporations do with foresight. Eur J Futur Res 2:1-20 https://doi.org/10.1007/s40309-014-0042-9

30. FoRS (2019) Seznam členů a pozorovatelů FoRS. http://www.fors.cz/clenovea-pozorovatele/seznam-clenu-a-pozorovatelu/\#.XRzAOuj7RPZ. Accessed 10 Feb 2019

31. Zelený kruh Členové - Zelený kruh. http://www.zelenykruh.cz/o-nas/clenove. Accessed 10 Feb 2019

32. Pavučina SSEV Členové - Pavučina SSEV. http://www.pavucina-sev.cz/ rubrika/59-CLENOVE/index.htm. Accessed 10 Feb 2019

33. Platforma MVRO (2012) Riadni členovia - Platforma MVRO. http://www.mvro. sk/old/en/members/full-members. Accessed 1 May 2019

34. Givt Organizace - Givt. https://givt.cz/organizace. Accessed 10 Feb 2019

35. Zoznam.sk (2019) Združenia, neziskové organizácie, nadácie. https://www. zoznam.sk/katalog/Institucie-urady/Zdruzenia-neziskovky/. Accessed 1 May 2019

36. OECD (2008) Handbook on constructing composite indicators: methodology and user guide

37. Bernardo M, Casadesus M, Karapetrovic S, Heras I (2009) How integrated are environmental, quality and other standardized management systems? An empirical study. J Clean Prod 17:742-750. https://doi.org/10.1016/j.jclepro. 2008.11.003

38. Boccanfuso D, Ki JB, Ménard C (2009) Pro-poor growth measurements in a multidimensional model: a comparative approach. Work Pap (Groupe Rech en Économie Développement Int Univ Sherbrooke) 9:1-25

39. Olawale F, Garwe D (2010) Obstacles to the growth of new SMEs in South Africa: a principal component analysis approach. African J Bus Manag 4:729738

40. Oyekale TO, Oyekale SA (2013) Assessment of multidimensional poverty in rural and urban Nigeria: evidence from demographic and health survey (DHS). J Hum Ecol 42:141-154. https://doi.org/10.1080/09709274.2013. 11906588

41. Conneely KN, Boehnke M (2007) So many correlated tests, so little time! Rapid adjustment of P values for multiple correlated tests. Am J Hum Genet 81:1158-1168. https://doi.org/10.1086/522036

\section{Publisher's Note}

Springer Nature remains neutral with regard to jurisdictional claims in published maps and institutional affiliations. 